\title{
Da linguística da língua à linguística do discurso, e retorno ${ }^{1}$
}

Patrick Charaudeau*

\section{Resumo}

O termo linguística tornou-se ambíguo. Realça duas grandes tendências do ponto de vista da constituição do sujeito e da abordagem de análise. Uma está centrada no estudo dos sistemas da língua em suas várias dimensões; a outra mais centrada sobre seus usos, a linguagem como um ato e seus procedimentos de realização. Essas duas tendências não são exclusivas uma da outra; veremos como elas se articulam, mas em suas bases teórico-metodológicas, elas diferem suficientemente para que possamos distinguir - o que eu propus em outros escritos - uma linguística da língua e uma linguística do discurso.

Palavras-chave: Linguística da língua. Linguística do discurso. Atos de comunicação. Sentido.

\section{Introdução}

O termo linguística tornou-se ambíguo. A que noção ele nos remete? Em sua estreia, com a chegada do estruturalismo, ele foi reservado para estudos descritivos e não normativos da língua, opondo-se à gramática, dita tradicional. A linguística era, então, a disciplina que analisava os sistemas fonológico, morfológico, sintático e semântico das línguas. E, em seguida, seu domínio se expandiu para os aspectos sociológicos (sociolinguística), psicológicos (psicolinguística), etnológicos (etnolinguística) da língua, e de suas diversas utilizações: comunicacional, conversacional, etnográfica, engendrando correntes disciplinares tais como a semiótica e a análise do discurso.

Isto é dito de forma rápida e desconsiderando-se a multiplicidade de teorias e

\footnotetext{
Université de Paris 13, CNRS-LCP.
}

Tradução de Bianca M. Q. Damacena e Fabiane V. Burlamaque - Universidade de Passo Fundo (UPF).

Data de submissão: jul. 2014 - Data de aceite: ago. 2014 http://dx.doi.org/10.5335/rdes.v10i2.4155 
metodologias que nasceram para tentar dar conta de seus diferentes aspectos e a sua combinação. Mas realçam-se, nesse conjunto pouco heterogêneo, duas grandes tendências do ponto de vista da constituição do sujeito e da abordagem de análise. Uma que está centrada no estudo dos sistemas da língua em suas várias dimensões, como já foi dito, a outra mais centrada sobre seus usos, a linguagem como um ato e seus procedimentos de realização. Essas duas tendências não são exclusivas uma da outra; veremos como elas se articulam, mas em suas bases teórico-metodológicas elas diferem suficientemente para que possamos distinguir - o que eu propus em outros escritos - uma linguística $d a$ língua e uma linguística do discurso.

É do ponto de vista semântico que quero mostrar o que justifica essa distinção. Por causa desse ponto de vista, somos obrigados a nos questionar não apenas o significado das palavras, em si, mas o sentido que eles transmitem. Roland Barthes, sempre pertinente, lembrou que se o signo "significa", e esquecemos que ele "significa a". ${ }^{2}$ Efetivamente, o fenômeno de significação resulta nessas duas orientações: uma orientação centrípeta que tende a estabilizar o sentido em si mesmo, uma orientação centrífuga que tende a construir o sentido em função de suas condições de utilização nos atos de comunicação. Podemos dizer que a linguagem significa ao mesmo tempo em que transmite o sentido, que é, no ato de transmissão, que ele significa com uma intenção de produzir certo efeito sobre o outro da linguagem. Interroguemo-nos, pois, sobre esse duplo sentido que diremos de língua e de discurso.

\section{O sentido da língua não é o sentido do discurso}

Seja o enunciado: "Eu tenho 30 anos". Uma análise semântica, fora de contexto, mostraria que se trata de uma afirmação na qual a certo sujeito do ato $(E u)$ é atribuída (ter) uma certa propriedade (anos), a qual é quantificada (trinta), tudo num ato de enunciação que diz que essa asserção deve ser comunicada ao sujeito falando ele mesmo $(E u)$ numa modalidade elocutiva de afirmação. Se, além disso, consultamos um dicionário, aprendemos que esse "anos" refere-se a certa segmentação do tempo, e que, combinada com uma certa quantificação (de um a cem), pode designar uma idade da vida.

Se agora considerarmos esse enunciado num contexto comunicacional, de um determinado locutor, como uma resposta a uma asserção anterior. Por exemplo, suponhamos que um locutor, conversando com um amigo que fica surpreso ao vê-lo retirar-se da competição esportiva, replica: "Eu tenho trinta anos"; então, esse enunciado significará: "Estou velho". Obviamente, isso implica que o locutor em questão é um atleta e que o interlocutor o sabe. Imaginemos agora que se trata de uma pessoa que acaba de ser despedida de uma empresa, que 
informa um de seus amigos e que esse tenta uma explicação: "Pode ser porque você já passou da idade?"; então o enunciado "Tenho trinta anos" significará algo como: "No entanto, ainda sou jovem".

Portanto, podemos propor a questão de saber qual gramática e qual dicionário poderiam dizer que esse enunciado significa "velho" ou "jovem"? Uma coisa é o que significam as palavras na língua, outra coisa é o que elas significam no contexto comunicacional, aquele que determina a expectativa do ato de linguagem. É que a expectativa do ato de linguagem não se encontra nem no explícito que é dito (a língua), nem no implícito que veicula, é a combinação das duas que fabrica os discursos. Todo ato de linguagem, constitutivamente, tem uma dupla dimensão, explícita e implícita, indissociável uma da outra.

\section{Duas conceituações do signo}

Dessa observação, podemos apontar certo número de consequências em relação ao modo de conceber o que seria a conceituação do signo linguístico:

-) o signo da língua, de acordo com uma tradição agora bem estabelecida, define-se segundo uma tripla dimensão: estrutural, porque ele se informa e se semantiza sistemicamente no cruzamento de co-ocorrências sintagmáticas (combinação de trinta e anos) e das objeções paradigmáticas ( $E u$ não é $T u$, ano não é mês, e reciprocamente); contextual, na medida em que é investido de sentido por um contexto linguístico que deve garantir uma certa isotopia; referencial na medida em que todo signo refere-se a uma realidade do mundo do qual ele construiu a significação.

-) o signo do discurso se define de acordo com uma dupla dimensão: situacional e enunciativa, porque depende para seu sentido dos componentes da situação de comunicação e de um certo processo de enunciação em que ele aparece; interdiscursivo (ou intertextual) ${ }^{3}$, porque seu sentido depende também dos discursos produzidos que constituem os domínios do saber normatizado.

Isso explica que o signo da língua seja indexável, categorizável, e que seu sentido surja do provável, porque entre um conjunto de sentidos possíveis, tendo em vista as combinações sintagmáticas e de oposições paradigmáticas, todo receptor ou observador ouvirá, provavelmente, a mesma coisa. Por exemplo: dados os sentidos possíveis de ano, sua quantificação, sua atribuição a uma pessoa, ouviremos sobre o sentido provável de: "idade", que o dicionário poderá confirmar como um dos sentidos possíveis. $O$ signo do discurso não é categorizável, pois ele sempre é dependente de outra coisa do que de si mesmo, de algo externo ao enunciado, seu sentido sob o plausivel. Por exemplo: foi apresentada a situação de um desportista de alto nível que fala justificando sua retirada dessa atividade. Sabendo-se sobre o limite de idade dos atletas de competição, podemos 
inferir, plausivelmente: "que ele é muito velho", e nesse caso, o dicionário será inútil. Da mesma forma, se uma palavra como "intelectual", em um enunciado do tipo: «Este é um intelectual!», pode ter tanto um valor positivo, como um valor negativo, é porque circulam nos grupos sociais discursos que, quer seja, opõem os intelectuais aos atletas ou a pessoas que sabem envolver-se fisicamente em ações (valor negativo), quer seja, contra aqueles que agem por impulso, sem se controlar, sem pensar (valor positivo).

Vimos, portanto, que o signo torna-se objeto de uma dupla conceituação: uma conceituação linguística (da língua) que se faz num duplo movimento de semantização entre o universal e o particular, o particular e o universal, em níveis mais ou menos abstratos, como mostrado no trabalho dos semanticistas e as teorias dos protótipos e do topos ${ }^{4}$; uma conceituação discursiva (do discurso) que é feita num duplo movimento de semantização entre uma norma social e uma especificidade individual de saberes, aqui sendo concebido como um conjunto de conhecimentos e de crenças compartilhadas. Vemos que, para determinar o sentido do discurso, é preciso recorrer ao contexto. Mas, qual é o contexto?

\section{Sobre a diversidade de contextos}

Eis ainda uma noção que convém em todas as circuntâncias. Quando ela é definida, tanto de maneira geral (tudo é contexto), quanto de maneira restritiva, como o conjunto de co-ocorrências que rodeia fisicamente uma inidade linguística; ou ela se confunde com a situação de comunicação (o contexto de uma conferência), ou ela designa mais amplamente a dimensão cultural de um fenômeno (o contexto americano ou o contexto francês).

Caso adote-se o ponto de vista do sujeito falante em sua função de produção da linguagem, pode-se supor que para realizar seu ato de linguagem, ele leva em conta, ao mesmo tempo, o ambiente linguístico imediato do enunciado, a situação de enunciação e os discursos já produzidos. Caso adote-se o ponto de vista do receptor em sua função de interpretação, é fácil constatar que ele deve recorrer a inúmeros tipos de contexto: um contexto linguístico constituído por co-ocorrências que permitem determinar o sentido primeiro das palavras; um contexto textual constituído por textos produzidos por uma mesma fonte (por exemplo, as diversas obras de um mesmo autor) que possibilita, por exemplo, alcançar o significado da palavra "olho" em Baudelaire; um contexto paratextual constituído por textos ou fragmentos de textos que se encontram em copresença, em um mesmo espaço textual (os títulos, subtítulos, capítulos, legendas de uma página de jornal); um contexto hipertextual ${ }^{5}$, constituído por textos que se citam, se reenviam uns aos outros, se retomam e se transformam, como os pastiches e as paródias; um contexto 
intertextual (ou interdiscursivo), constituído por textos e discursos que circulam em um espaço social, e que são evocados pelo sujeito receptor para justificar suas interpretações.

A esses diferentes tipos de contextos, falta adicionar um contexto que considera igualmente um "fora do texto" (às vezes chamados cotexto), quer dizer, os dados presentes nas condições de produção do ato de linguagem: o contexto situacional. ${ }^{6}$ Trata-se, aqui, da situação de comunicação que nos obriga (estejamos em posição de interlocutor, de leitor ou ainda de analista) a nos perguntar sobre a identidade daquele que fala (um atleta, um tabalhador), sobre a finalidade de troca (informar) que determina a expectativa de significação da troca linguageira, sobre o dispositivo e as circunstâncias materiais (conversação) deste. Este conjunto de componentes constitui as condições de produção do discurso.

\section{As três dimensões do ato de linguagem}

Tal observação propaga que a atividade linguageira dos seres falantes se apoie, ao mesmo tempo, em uma memória linguística (a organização dos sistemas), uma memória interdiscursiva (os saberes supostamente partilhados) e uma memória situacional (as condições psicológicas e sociológicas do ato de comunicação). Movimentos centrípeto e centrífugo, a partir da articulação dos quais se constroi o sentido que consiste de sujeitos que falam do mundo através de sua relação com o outro. Também pode-se dizer que o ato de linguagem compreende três dimensões:

- uma dimensão topicalisante onde se constroem os saberes do mundo: saberes de conhecimento e saberes de crença que constituem os «imaginários sociais» que caracterizam uma sociedade. Quer dizer, a maneira como os indivíduos em sociedade representam o mundo e julgam os comportamentos humanos, organizando tais saberes em doutrinas, ideologias ou simplesmente opiniões mais ou menos estereotipadas. É este fenômeno de circulação e de entrecruzamento de palavras que se trocam em um espaço público ou interpessoal, que é chamado, às vezes, de «intertextualidade» (Genette) ${ }^{7}$, às vezes de «dialogismo» $(\text { Bakhtin })^{8} \mathrm{e}$ às vezes de «interdiscursividade».

- Uma dimensão enunciativa onde acontece a encenação (mise en scène) discursiva com sua organização descritiva, narrativa, argumentativa, enunciativa e a escolha de palavras do léxico que a acompanha. Entretanto, aqui é conveniente distiguir a enunciação do ponto de vista da língua e do ponto de vista do discurso, ainda que o dois sejam intimamente ligados $^{9}$. Do ponto de vista da língua, a enunciação foi definida 
pelos textos, considerados fundadores, de Emile Benveniste ${ }^{10}$ que coloca a presença dos sujeitos $E u$ e Tu como determinante para $o$ ato mesmo da língua à medida que falar é sempre para um locutor $E u$ se dirigir a um interlocutor $T u$, o qual pode, por sua vez, tomar a palavra. Estabelece-se assim entre eles uma relação de reciprocidade não simétrica: não há $E u$ sem $T u$, assim como não há $T u$ sem $E u$. A partir deste princípio de funcionamento da linguagem - que determina a presença do «homem na língua»-, Benveniste descreve que ele chama de aparelho formal da enunciação ${ }^{11}$, isto é, o conjunto de formas e sistemas linguísticos que exprimem de uma forma ou de outra os diferentes posicionamentos do sujeito falante em relação a seu interlocutor e àquilo que ele diz: os pronomes pessoais de 1a e 2a pessoas (posicionamento de locutores), os tempos dos verbos e os advérbios de tempo (posicionamento no tempo), os dêiticos (posicionamento em relação ao espaço), os verbos, os advérbios de modalidade e o discurso relatado (posicionamento em relação ao enunciado), e por fim, os adjetivos afetivos (posicionamento em relação à subjetividade do locutor). Do ponto de vista do discurso, a enunciação engloba a totalidade do ato de linguagem. É o processo pelo qual um sujeito falante encena seu dizer, ordenando-o em função de diversos parâmetros que o permitem construir uma descrição, um relato, uma argumentação, etc. No entanto, tratam-se de duas definições da enunciação em que vemos como elas se articulam, a concepção discursiva que determina a encenação do ato de linguagem, mas graças à concepção linguística que forncece ao sujeito falante o aparelho de marcas linguísticas com as quais ele poderá se expressar.

- Uma dimensão comunicacional que obriga a levar em consideração o aspecto externo do ato de linguagem, onde se encontram suas condições psicossociais de produção e de interpretação. Não se pode falar, escrever ou interpretar se não se considerar estas pré-determinações. É isto que faz com que uma mesma frase não tenha o mesmo sentido e não produza o mesmo efeito de acordo com a situação na qual foi produzida: quem fala para quem (identidade), com qual expectativa (finalidade), em qual dispositivo (gênero). Tal conjunto de condições de produção/interpretação situacionais constitui um contrato de comunicação, espaço de restrições, que dá instruções discursivas ao sujeito falante, restrições que ele deverá seguir para realziar o seu 
ato de enunciação, e as quais o sujeito interlocutor deverá considerar para interpretar. A situação de comunicação não se confunde, portanto, com a situação de enunciação: a primeira diz respeito às condições externas de produção (englobante), a segunda, a encenação (mise en scène) discursiva (especificante), acontece em função das instruções dadas pela primeira, e recorre ao aparelho da enunciação que lhe fornece $o$ sistema linguístico.

\section{O sentido se constrói por inferência}

O sentido se constroi a partir da articulação dessas três dimensões, isto é, ele não é aquilo que emana de um único enunciado, mas daquilo inscrito em um conjunto de condições de produção. Além disso, somente a intenção do sujeito falante não é mais o que constitui a totalidade do sentido, pois sempre há um sujeito interpretante que também constroi o sentido e, portanto, é no encontro entre os dois parceiros da troca linguageira em uma dada situação que surge um conjunto de sentidos possíveis. $O$ sentido de um ato de linguagem, qualquer que seja, é sempre o resultado de uma co-construção.

Uma frase como "Os negros são diferentes dos brancos» não é racista em si. Ela o será se soubermos: quem a pronuncia (por exemplo, um ator político de extrema direita cujos discursos são explicitamente racistas); em qual dispositivo (por exemplo, uma entrevista jornalística, durante uma campanha eleitoral); em qual encenação enunciativa (uma constatação empírica que se propõe como evidência para justificar uma discriminação social). Porém, esta mesma frase pronunciada por um etnólogo que está descrevendo o estatuto que ocupam os indivíduos em uma população mestiça, não terá efeito racista.

Dessa forma, vê-se que a produção do sentido provém de um sujeito locutor ou de um sujeito receptor, resulta de uma atividade inferencial, não necessariamente previsível, porque se apoia em diversos contextos. E, de acordo com o tipo de contexto ao qual se refere, poderá acontecer inferências contextuais, situacionais ou interdiscursivas, como representa o esquema a seguir:

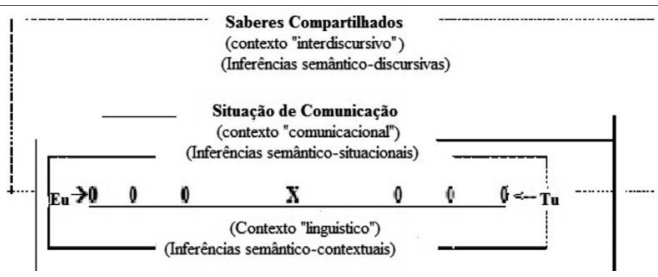

O sentido do discurso não é, portanto, como já se quis dizer em um dado momento, uma transposição do sentido da frase para algo além disso. Pois o sentido da frase é da ordem da predicação, enquanto que o sentido do discurso é da ordem da problematização. Sentido de língua e sentido de discurso não seguem os mesmos procedimentos de cálculo: o 
primeiro se obtém por um cálculo dedutivo de probabilidade, o segundo, pelo cálculo de inferência plausível de acordo com os três tipos acima descritos.

\section{Do sentido da língua ao sentido do discurso via enunciação}

Depois de ter distinguido estes dois tipos de signo, estes dois procedimentos de cálculo do sentido, poderíamos nos perguntar se não existe ainda uma ligação entre os dois, pois se pode defender também a ideia de que a linguagem é um todo que dentro de suas diferentes realizações tece uma teia semântica, às vezes um labirinto, onde cada fio está ligado de maneira mais ou menos direta aos outros. Esta ligação, para mim, se encontra na enunciação, no procedimento da encenação enunciativa. Pois é por ela que se entrelaçam os sentidos da língua e do discurso. A partir do entrelaçamento, aquilo que depende do acaso dos contextos acaba por se inscrever na língua, e o sentido do discurso plausível, específico de uma situação particular, geralmente se junta aos outros traços semânticos do signo que se constitui por sedimentação em uma potencialidade de sentido, posteriormente disponível para outros empregos. É assim que evoluem as línguas. Se «30 anos» pode significar «jovem» ou «velho», se «intelectual» pode significar uma qualidade positiva ou negativa, não quer dizer que tais termos sejam diretamente portadores desses sentidos (uma vez mais, não se poderia categorizá-los em um dicionário), é que essas palavras possuem em seu semantismo algo (um ou mais traços) que - sem ser explícito - está potencialmente disponível, algo que lhes dá a capacidade de «receber» sentidos não previstos que são levados pelo contexto interdiscursivo do qual já falei. É também esta virtualidade que possibilita explicar a evolução do sentido das palavras. Como explicar que se passou do «purros» grego, que significava «vermelho» e «fogo», para o latin «burra», que significava «tecido de pelos compridos», para «robe de bure» (vestido de batina), «bourrelet» (rolo) e «bourreau» $(\text { carrasco })^{12}$ se não foi por esse jogo de virtualidades sucessivas que se recebeu o sentido que não estava previsto a cada um desses estágios e que se construiu na interdiscursividade?

É, então, por intermédio do processo de enunciação que se estabelece uma ligação potencial entre sentido de língua e sentido de discurso com a condição de admitir, entretanto, que isto não se dá necessariamente por continuidade. Antes, o sentido de discurso, que chega a partir dos saberes que se constroem na prática social, encontra-se posteriormente como incubado no sentido da língua que depois de alguma hesitação acaba por aceitar, e até integrá-lo ao ponto de, talvez, se apropriar dele e de categorizar em uma nova denotação. 


\section{Considerações finais}

Para finalizar, percebe-se ao terminar esta demonstração que uma linguística do discurso pressupõe uma linguística da língua: a primeira não pode existir sem a segunda. Em contrapartida, é preciso aceitar e considerar que uma linguística da língua não pode, somente ela, pretender dar conta do sentido dos atos de linguagem produzidos em situação de comunicação real: ela necessita ser complementada por uma linguística do discurso. Tanto num caso como no outro, trata-se de investigar o sentido. Uma dupla investigação, através de um cálculo probabilístico e inferencial, não necessariamente previsível, sobre um mesmo terreno de virtualidades de sentido, e sempre em um movimento de vai-e-vem entre o geral e o particular.

\section{De la linguistique de la langue à la linguistique du discours, et retour}

\section{Résumé}

Le terme de linguistique est devenu ambigu. Il ressort deux grandes tendances du point de vue de la constitution de l'objet et de la démarche d'analyse. L'une qui est centrée sur l'étude des systèmes des langues dans leurs diverses dimensions; l'autre davantage centrée sur les usages, le langage en tant qu'acte et ses procédés de mise en scène. Ces deux tendances ne sont pas exclusives l'une de l'autre; on verra comment elles s'articulent, mais en leur fondement théorico-méthodologique elles se différencient suffisamment pour que l'on puisse distinguer —ce que j'ai proposé dans d'autres écrits- une linguistique de la langue et une linguistique du discours.

Mots-clés: Linguistique de la langue. Discours linguistique. Des actes de communication. Sens.

\section{Notas}

1 Tendo sido levado a desenvolver este ponto de vista em outras conferências, aqui encontramos partes de uma mesma demonstração.

2 Roland Barthes par Roland Barthes, Seuil, Coll. "Écrivains de toujours", Paris, 1975. Nota da tradutora: a referida obra foi publicada no Brasil sob o título de Roland Barthes por Roland Barthes, pela editora Estação Liberdade.

3 Aqui, não faremos distinção entre estes dois conceitos.

4 Ver Martin R., "Typicité et sens des mots", in Dubois D. (éd.), Sémantique et cognition. Catégories, prototypes, typicalité, Éditions du CNRS, p. 151-159, Paris, 1991; et Anscombre J.-C. et Ducrot O., L'argumentation dans la langue, Mardaga, Liège, 1983.

5 Os contextos paratextual, metatextual e hipertextual são propostos por G. Genette

6 Às vezes chamado de "Contexto comunicacional".

7 Genette G. Palimpsestes, Le Seuil, coll. «Poétique ", 1982.

8 Bakhtine M., Écrits du cercle de Bakhtine, in Todorov, T.; Mikhaïl Bakhtine, le principe dialogique, Seuil, Paris, 1981.

9 Ver Dicionário de Análise do Discurso, Seuil, Paris, 2002.

10 Ver Problemas de linguística geral, Gallimard, Paris, 1966, (particularmente o capítulo intitulado «O homem na língua»).

11 Benveniste E., "O aparelho formal da enunciação", Revista Langages n ${ }^{\circ}$ 17, Didier-Larousse, Paris, março 1970.

12 Nota do Tradutor: as palavras robe de bure, bourrelet e bourreau, foram mantidas em francês porque o que o autor coloca é que embora haja semelhança na raíz dessas palavras com relação aos termos grego e latino, o sentido se modificou com o tempo. 


\section{Referências}

AN S C OMBRE, J.-C. Ducrot O.; L'argumentation dans la langue, Mardaga, Liège, 1983.

BAKHTINE, M. Écrits du cercle de Bakhtine. In: TODOROV, T. Mikhaïl Bakhtine, le principe dialogique, Seuil, Paris, 1981.

BARTHES, R., Roland Barthes par roland barthes, Seuil, coll. "Écrivains de toujours", Paris, 1975.

BENVENISTE, E. "L'appareil formel de l'énonciation", Revue Langages $\mathrm{n}^{\circ} 17$, Didier-Larousse, Paris, mars 1970.

Problèmes de linguistique générale, Gallimard, Paris, 1966.

CHARAUDEAU, P. et Maingueneau D., Dictionnaire d'Analyse du Discours, Seuil, Paris, 2002.

GENETTE, G., Palimpsestes, Le Seuil, coll. «Poétique », 1982.

MARTIN, R., "Typicité et sens des mots", in Dubois D. (éd.), Sémantique et cognition. Catégories,prototypes, typicalité, Éditions du CNRS, pp. 151-159, Paris, 1991. 